\author{
Vol. 55, z. $2-2002$
}

s. $65-74$

\title{
Proline and hydroxyproline containing cell wall proteins of red raspberry (Rubus idaeus L.) cane cortex
}

\section{HANNA BANDURSKA, MONIKA KOZŁOWSKA, MAŁGORZATA ZIELEZIŃSKA}

\author{
Department of Plant Physiology August Cieszkowski Agricultural University \\ 60-637 Poznań, Wołyńska 35, POLAND
}

(Received: 29.04.2002)

\section{Summary}

The formation of insoluble wall bound proline-rich proteins (PRPs) and hydroxyproline-rich glycoproteins (HRGPs) in relation to the growth stage and developmental changes was examined in red raspberry primocane cortex. Two cultivars 'Latham' and 'Malling Promise' - differing in growth intensity and in sensitivity to biotic stress were used for the experiments. The level of insoluble cell wall bound PRPs of the cortical tissues was almost similar in the course of the plants growth period. HRGPs were significantly higher at the end of the vegetation season (August /September), especially in 'Malling Promise'.

The plant sensitivity to biotic stress, based on the response to the fungus Didymella applanata changed in the period of vegetative growth. At the end of summer the both cultivars became more resistant. It has been inferred that the insolubilization of wall PRPs and HRGPs was responsible for the acquiring resistance to $D$. applanata by 'Malling Promise', which was previously very susceptible to this fungus.

Key words: raspberry, biotic stress, growth, development, cell wall, proline-rich proteins, hydroxyproline-rich glycoproteins

\section{INTRODUCTION}

Amino acid proline as a constituent of tissue of many plants has been the subject of intensive research. It has been observed that free proline accumulates in certain plants subjected to various environmental stresses (Das hek and Ericson 1981, Hare and Cress 1997). Moreover, proline has a unique function involved in osmotolerance and cell morphogenesis ( $\mathrm{Nanj}$ o et al. 1999, Yamaguchi-Shinozaki and Shinozaki 1999). Together with its analogue hydroxyproline, proline 
has been found to be the major component of structural proteins. Proline-rich proteins (PRPs) and hydroxyproline-rich glycoproteins (HRGPs) belong to important cell wall components of higher plants (Cassab and Varner 1988, Ye et al. 1991). Their synthesis and cross-linking are under developmental control and can be regulated by a number of environmental factors (Keller 1993). In addition, rapid insolubilization of preexisting PRPs and HRGPs into cell walls is an important process of disease resistance (B radley et al. 1992, L a mb et al. 1993). The observation mainly refers to the primary cell walls of herbaceous plants.

Red raspberry belongs to woody plants, the shoots of which undergo physiologically significant termination of wall extensibility and cell wall strengthening. These processes, besides lignification, can involve covalent cross-linking of structural proteins (B a c ic et al. 1988, Liy a m a et al. 1994). The present study describes the formation of insoluble wall bound PRPs and HRGPs in relation to the growth stage and development of raspberry canes. It was also examined whether the insolubilization of wall PRPs and HRGPs could be responsible for the acquirement of resistance to pathogenic fungus. Cultivars 'Latham' and 'Malling Promise' differing in growth intensity and in sensitivity to Didymella applanata were used for the experiments.

\section{MATERIAL AND METHODS}

\section{Plant material}

Two red raspberry (Rubus idaeus L.) cultivars, 'Latham' resistant (R) and 'Malling Promise' susceptible (S) to biotic stress, were grown in an experimental field under standard fertilization and tillage treatments. For biochemical analysis the vegetative primocanes were harvested twice during the vegetation season. At first, the canes were collected during their intensive growth - in early summer (June/July) and again in late summer (August/September), in the course of developmental changes. Plant material was sampled three or four times during each period at 6-7 day intervals. Cortical regions were separated from the middle cane zones $(40-80 \mathrm{~cm}$ above soil surface), weighed and frozen in liquid nitrogen and kept at $-40^{\circ} \mathrm{C}$ until use.

\section{Extraction procedure}

The frozen material $(100 \mathrm{mg}$ ) was ground in $2 \mathrm{ml}$ of $0.1 \mathrm{M}$ sodium citrate buffer, $\mathrm{pH} 6.0$ at $4^{\circ} \mathrm{C}$. The homogenate was centrifuged at $3000 \mathrm{~g}$ for $15 \mathrm{~min}$ at $4^{\circ} \mathrm{C}$. The pellet was washed three times by resuspension in $2 \mathrm{ml}$ of extraction buffer and centrifuged as above. The final pellet was freeze-dried in the Heto vacuum concentration system and used for the estimation of cell wall bound PRPs and HPRPs. The supernatants were collected and used for the estimation of cytoplasmic free and protein bound proline and hydroxyproline.

\section{Cell walls preparation}

Ten milligrams of dry cell wall material were hydrolysed in a test tube, fitted with a Teflon-lined screw top, with $400 \mu \mathrm{l}$ of $5.5 \mathrm{~N} \mathrm{HCl}$ at $110^{\circ} \mathrm{C}$ for $18 \mathrm{~h}$. After 
hydrolysis, the samples were dried, resuspended in $0.001 \mathrm{~N} \mathrm{HCl}$ and centrifuged for $1 \mathrm{~h}$ at $3600 \mathrm{~g}$. The supernatants were used for the determination of cell wall bound proline and hydroxyproline.

\section{Cytoplasmic fraction preparation}

Cytoplasmic proteins extracted by $0.1 \mathrm{M}$ sodium citrate buffer, $\mathrm{pH}$ 6.0, were precipitated with $10 \%$ trichloroacetic acid. After $15 \mathrm{~min}$ of centrifugation at $12000 \mathrm{~g}$ the supernatant was used for the estimation of free proline and hydroxyproline. The pellet containing proteins was dried, hydrolized with $5.5 \mathrm{~N} \mathrm{HCl}$ at $110^{\circ} \mathrm{C}$ for $18 \mathrm{~h}$, resuspended in $0.001 \mathrm{~N} \mathrm{HCl}$ and centrifuged for $1 \mathrm{~h}$ at $3600 \mathrm{~g}$. The supernatant was used for protein bound proline and hydroxyproline.

The content of protein was determined according to B radford (1976) using bovine serum albumin as a standard.

\section{Analytical procedure \\ Proline determination}

Proline content was estimated using the method of B ates et al. (1973) consisting in colorimetric determination of the amount of the coloured reaction product of proline with ninhydric acid. The absorbance was read at $520 \mathrm{~nm}$ wavelength and the amount of proline was calculated from the previously plotted standard curve.

\section{Hydroxyproline determination}

Hydroxyproline content was determined according to the method of $\mathrm{Kivi}$ rikko and Liesmaa described by Weissbach and Weissbach (1988). The method is based on the estimation of colorimetric absorption of the complex of amino acid with p-dimethylaminobenzaldehyde. The absorbance was determined at $560 \mathrm{~nm}$ wavelength and the amount of hydroxyproline was calculated from the previously plotted standard curve.

\section{Sensitivity test of red raspberry to Didymella applanata}

In the two experimental periods the plants were inoculated with the pathogenic fungus $D$. applanata, responsible for spur blight cane disease. The inoculation was carried out according to the point pattern with a 10-day-old culture of the pathogen. The mycelium slices $3 \mathrm{~mm}$ in diameter were applied to a little-injured surface of cane epidermis. For 5 days the inoculation points were wrapped with cotton wool and parafilm and sprayed with water to dampen the mycelium. The disease index was calculated 20 days after inoculation by evaluating lesion length and width.

\section{Presentation of data}

The data are presented as means \pm standard deviation, which were marked in the plots as vertical bars. The results showed in Fig. 1 and 3 are means of 3 determinations and those in Fig 2 are means of 12 determinations. 


\section{RESULTS}

\section{Cell wall PRPs and HPRGs content in the course of vegetative growth.}

Proline and hydroxyproline (Fig.1) contents in hydrolysed cell wall of cortical tissue fraction of red raspberry primocanes were used for the estimation of PRPs and HRGPs. In the early summer period, the level of proline was about twofold higher than that of hydroxyproline in the both cultivars. Proline level was the lowest in early summer (25 June) and almost equal in the both cultivars, i. e. $1.6 \mu \mathrm{g} \times 10 \mathrm{mg}^{-1}$ of dry cell wall in 'Latham' and 'M. Promise'. Subsequently a twofold increase was observed in the level of this amino acid, which ranged from 4.0 to 4.5 and 3.4 to $5.6 \mu \mathrm{g} \times 10 \mathrm{mg}^{-1}$ of dry cell wall in 'Latham' and 'Malling Promise', respectively. Hydroxyproline content ranged from 0.9 to $1.9 \mu \mathrm{g} \times 10 \mathrm{mg}^{-1}$ of dry cell wall in 'Latham' and from 1.2 to $3.1 \mu \mathrm{g}$ $\times 10 \mathrm{mg}^{-1}$ of dry cell wall in 'Malling Promise'.

At the end of the vegetation season (August/September) the cv. Malling Promise showed a twofold higher proline level at two final dates, while 'Latham' showed only 1.5 - fold increase at the last date. The level of hydroxyproline was several times higher in 'Malling Promise' and only twofold higher in 'Latham' at all the dates in late summer than in early summer.

\section{Free and soluble protein bound proline and hydroxyproline contents in the course of vegetative growth}

Fig. 2 shows free and soluble protein bound proline and hydroxyproline contents in the cytoplasmic fraction during two growth periods. Since the results of estimation at four sampling dates in each period did not differ they are presented as means of all estimations. Independently of the growth period and cultivar, the levels of hydroxyproline were several times lower than that of proline. Moreover, free hydroxyproline and proline of 'Malling Promise' were higher in late summer than in early summer. The level of soluble protein bound proline and hydroxyproline did not change in the course of the vegetative growth and was slightly lower in 'Malling Promise' than in 'Latham'.

\section{Disease index of investigated cultivars inoculated with Didymella applanata in early and late summer periods}

The resistance level changed in the both cultivars in the course of the vegetative growth (Fig. 3). In the early summer the degree of disease symptoms was nearly 3-fold higher in the susceptible 'Malling Promise' than in the moderately resistant 'Latham'. At the end of the vegetation season the resistance level significantly increased, especially in 'Malling Promise', and differences between the cultivars were invisible.

\section{DISCUSSION}

At the early growth stage, the studied red raspberry cultivars were found to have a similar content of insoluble cell wall proline-rich proteins of the cane cortex. 


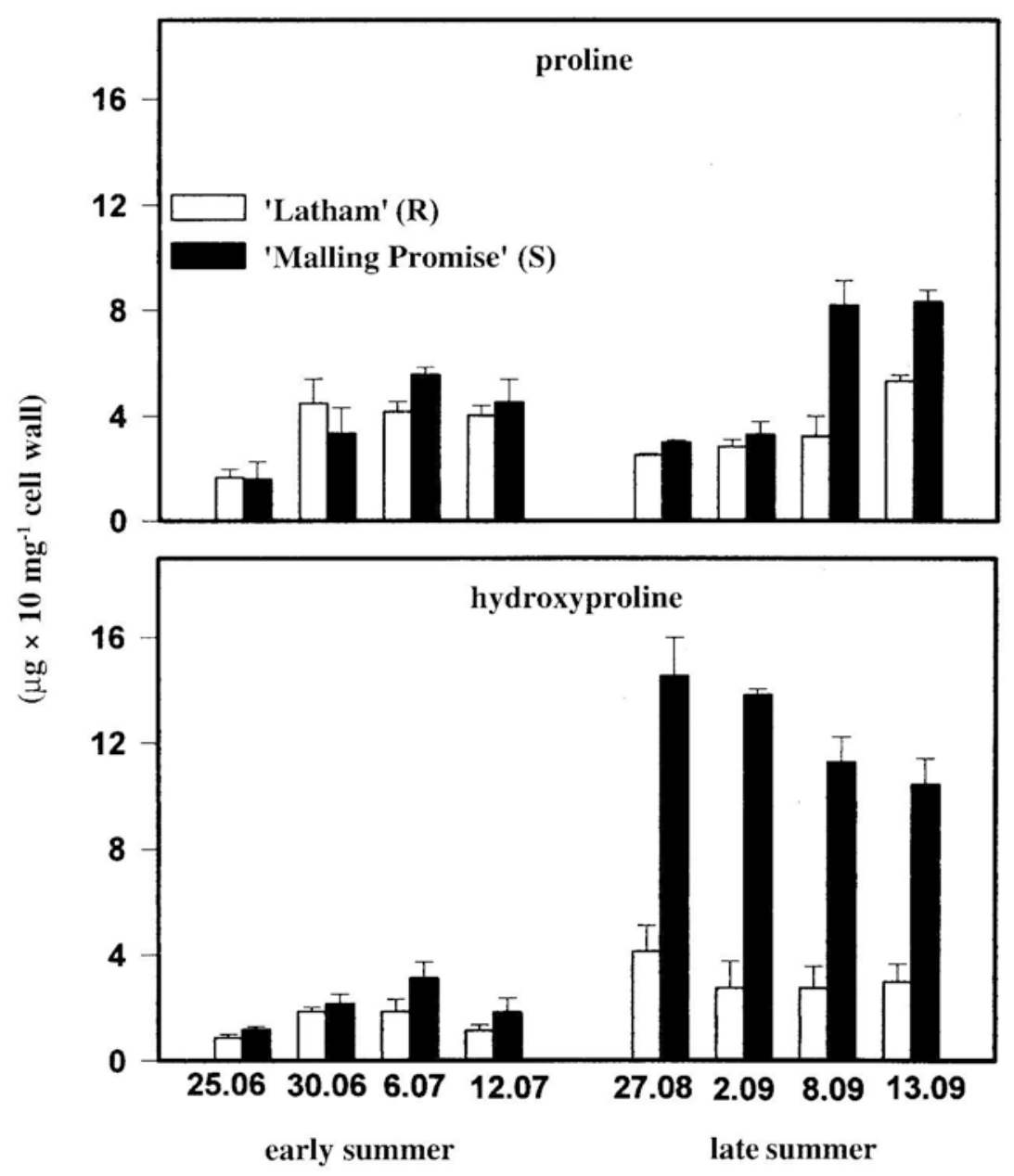

\section{Dates of sampling}

Fig. 1. Cell wall bound proline (PRPs) and hydroxyproline (HRGPs) in two red raspberry cultivars in early and late summer periods; 'Latham' (R) - resistant and 'Malling Promise' susceptible to biotic stresses 


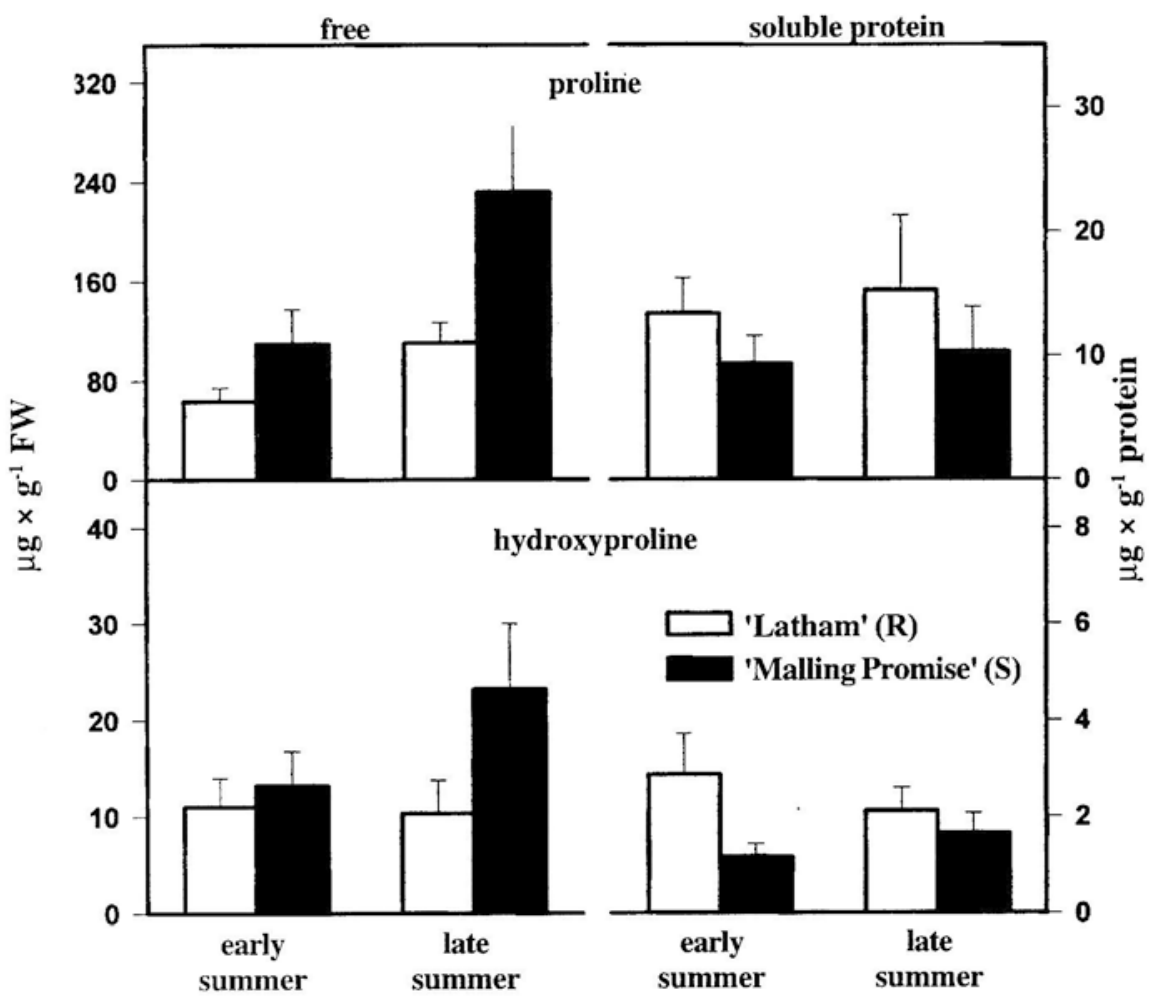

Fig. 2. Cytoplasmic free and protein bound proline and hydroxyproline in two red raspberry cultivars in early and late summer periods.

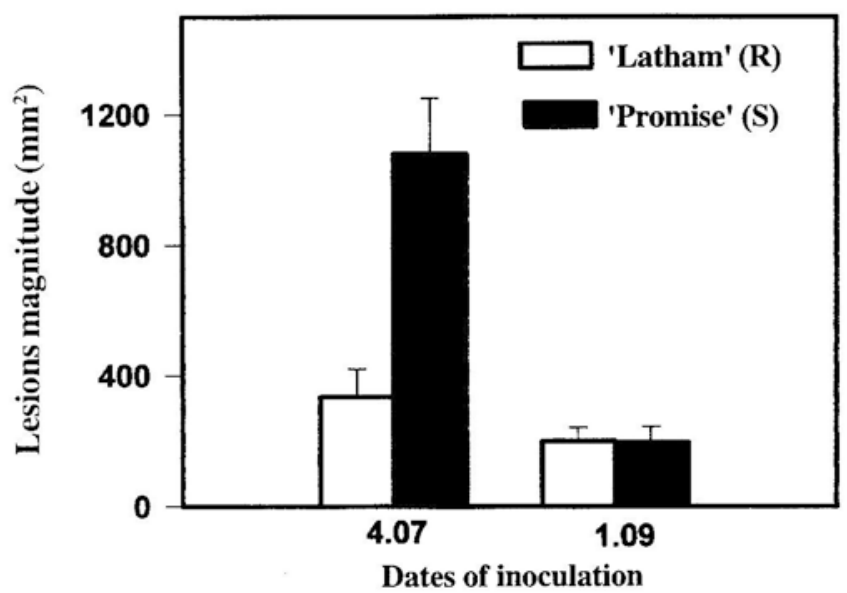

Fig. 3. Disease index of two red raspberry cultivars inoculated with Didymella applanata in early and late summer periods. 
A twofold increase in the level of these proteins occurred in 'Malling Promise' in the late summer period (Fig. 1). Larger differences between the cultivars as well as changes in the course of their growth were found in the content of insoluble hydroxyproline-rich glycoproteins (Fig.1). In the early and late summer, the level of cell wallbound hydroxyproline was higher in 'Malling Promise' than in 'Latham'. Moreover, in the latter period, the level of hydroxyproline increased in the both genotypes, being several times higher in 'Malling Promise'.

Many studies have demonstrated that genes encoding cell wall PRPs are developmentally regulated, showing stage- and organ-specific expression (D at t a et al. 1989, Kleis-San Francisco and Tierney 1990, Suzuki et al. 1993). Changes in the expression of PRPs in Cicer arietinum (chickpea) during development and abiotic stress have been reported by $\mathrm{Munoz}$ et al. (1998), who postulated that these proteins play an important role in the cell wall-hardening process, when growth is ceased either developmentally or under stress conditions. The results presented in this paper partly support observations of developmentally regulated synthesis of PRPs in the cell wall. This was indicated by a higher level of free proline (Fig. 2) and proline bound to the cell walls (Fig. 1) in the late summer period as compared to the levels of these substance in the early summer, observed in 'Malling Promise'.

In Avena coleoptile proline was a precursor of protein-bound hydroxyproline and hydroxyproline was incorporated into protein but only after convertion to proline (Cleland and Olsen 1967). According to Kieliszewski and Lamport (1994) hydroxyproline-rich proteins are synthesized at ribosomal level as ordinary proline-containing polypeptyde chains and proline residues present in the chain are hydroxylated by means of a prolyl-hydroxylase (Adams and Frank 1980). Our results have confirmed that proline could be the main precursor of HRGPs, because the level of free proline found in the examined plants was multiply higher than that of hydroxyproline (Fig. 2). It may be suggested that the synthesis of proline-rich proteins proceeded in the late summer period and then was followed by hydroxylation of proline residues. Hydroxylation of proline residues is determined by the primary structure of polypeptides. PRPs have a Pro-Pro-X-Y-Lys pentapeptide repetitive motif, where only the second proline is hydroxylated (D a t a et al. 1989). The most abundant peptide motif of HRGPs are the Ser-(Pro) $)_{4}$ repeats where all proline residues are hydroxylated (Keller 1993, Kieliszewski and Lamport 1994).

In the raspberry cortex tissues (Fig. 2) no changes in the content of proline- and hydrohyproline-rich soluble cytoplasmic proteins have been found in the course of plant growth. This would be indicative of modifications of the cell wall proteins (particularly HPRPs) occurring in late summer period and leading to a decrease of their solubility and immobilization in that part of the cell. Formation of inter- and intramolecular bounds between cell wall polymers with participation of PRPs and HRGPs leads to its sealing and makes it less susceptible to degradation induced by the pathogen (Lindstrom and Vodkin 1991, Bradley et al. 1992). Based on experiments with soybean seedlings, Kleis-San Francisco and Tierney (1990) found that the expression of developmentally regulated cell wall PRPs and HRGPs is subject to a post-transcriptional control or that the rate of insolubilization of these 
proteins increases in a more mature tissue. This was considered to be a result of their modification and bound with other structural cell wall elements (Varner and Lin 1989).

Two studied red raspberry cultivars differed in the sensibility to the important and widespread pathogenic fungus Didymella applanata. The cv. 'Latham' originating from the Rubus idaeus var. strigosus distinguishes by a relatively high resistance to biotic stresses determined by an active defense mechanism, noted in the period of intensive cane growth. The cv. 'Malling Promise' originating from Rubus idaeus has small possibilities to restrict pathogenic microorganisms at the lack of active mechanisms (Kozłowska and Krzywański 1991, Kozłowska and Krzywański 1993, Kozłowska 1995, Fryder and Kozłowska 1999). The level of resistance in these cultivars increased in the late summer, which was especially evident in 'Malling Promise' (Fig.3). Taking into consideration the revealed increase of insolubilization of the cell wall hydroxyproline-rich glycoproteins it may be suggested that the acquired resistance in the susceptible 'Malling Promise' cultivar may be caused by formation of cross-linking with participation of structural proteins.

\section{REFERENCES}

Adams E., Frank L. 1980. Metabolism of proline and hydroxyproline. Ann. Rev. Biochem. 49: 1005-1061.

B acic A., Harris P.J., St one B.A. 1988. Structure and function of plant cell walls. Ed. by PK Stumpf, EE Conn, In: The Biochemistry of Plants: A Comprehensive Treatise, Carbohydrates. Academic Press, New York, pp 297-371.

Bates L.S., Waldren R.P., Teare J.D. 1973. Rapid determination of proline for water stress studies. Plant and Soil 39: 205-207.

Bradley D.J., Kjellbom P., Lamb C.J. 1992. Elicitor and wound-induced oxidative cross-linking of a proline-rich plant cell wall protein: a novel, rapid defence response. Cell 70: $21-30$.

B rad ford M.M. 1976. A rapid and sensitive method for the quantitation of microgram quantities of protein utilizing the principle of protein-dye binding. Anal. Biochem. 72: 248-254.

Cassab G.I., Varner J.E. 1988. Cell wall proteins. Ann. Rev. Plant Physiol. Plant Mol. Biol. 39: 321-353.

Cleland R., Olsen A. 1967. Metabolism of free hydroxyproline in Avena coleoptiles. Biochemistry 6: 32-36.

Datta K., Schmidt A., Marcus A. 1989. Characterization of two soybean repetitive proline-rich proteins and a cognate cDNA from germinated axes. Plant Cell 1: 945-952.

Dashek W.V., Erickson S.S. 1981. Isolation, assay, biosynthesis, metabolism, uptake and translocation, and function of proline in plant cells and tissues. Bot. Rev. 47: 349-385.

Fryder K, Koz to w sk a M. 1999. Resistance of red raspberry canes to Didymella applanata after physiological lignification and induced by pathogen. Phytopathol. Pol. 18: 95-102.

Hare P. D., Cress W. A. 1997. Metabolic implications of stress-induced proline accumulation in plants. Plant Growth Reg. 21: 79-102.

Ke1ler B. 1993. Structural cell wall proteins. Plant Physiol., 101: 1127-1130.

Kieliszewski M.J., Lamport D.T.A. 1994. Extensin: repetitive motifs, functional sites, post-translational codes, and phylogeny. Plant J. 5: 157-172. 
Kleis-San Francisco S.M., Tierney M.L. 1990. Isolation and characterization of proline-rich cell wall protein from soybean seedlings. Plant Physiol. 94: 1897-1902.

Kozłowska M., Krzywański Z. 1991. Lignification in red raspberry canes upon wounding and fungal infection. Acta Physiol. Plant. 13: 165-172.

Kozłowska M., Krzywański Z. 1993. Lignin deposition and its role in restriction of the penetration of Didymella applanata in red raspberry canes. In: Mechanisms of Plant Defense Responses. Ed. by B Friting and M. Legrand, Kluwer Academic Publishers. Netherlands, p. 357 (short article).

Kozłows ka M. 1995. Histopathological response of red raspberry canes to Didymella applanata (Niessl/ Sacc.) response. Acta Physiol. Plant. 16: 211-215.

Lamb C.J., Brisson, Bradley D.J., Kjellbom P. 1993. Stimulus-dependent oxidative cross-linking of a proline-rich plant cell wall protein: a novel, rapid defense response and control point in cellular maturation. In: Mechanisms of Plant Defense Responses. Ed. by B. Friting and M. Legrand, Kluwer Academic Publishers. Netherlands, pp. 250-256.

Lindstrom J.T., Vodkin L.O. 1991. A soybean cell wall protein is affected by seed color genotype. Plant Cell 3: 561-571.

Liy a ma K., Lam T. B-T., S tone B.A. 1994. Covalent cross-links in the cell wall. Plant Physiol. 104: 315-320.

Muňoz F.J., Dopico B., Labrador E. 1998. AcDNA encoding a proline-rich protein from Cicer arietinun. Changes in expression during development and abiotic stress. Physiol. Plant. 102: 582-590.

Nanjo T., Kobayashi M., Yoshiba Y., Sanada Y., Wada K., Tsukaya H., Kakubari Y., Yamaguchi-Shinozaki K., Shinozaki K. 1999. Biological functions of proline in morphogenesis and osmotolerance revealed in antisense transgenic Arabidopsis thaliana. Plant J. 18: 185-193.

Suzuki H., Fowler T.J., Tierney M.L. 1993. Deletion analysis and localization of SbPRP1, a soybean cell wall protein gene, in roots of transgenic tobacco and cowpea. Plant Mol. Biol. 21: 109-119.

Varner J.E., Lin L-S. 1989. Plant cell wall architecture. Cell 56: 231-239.

Weissbach A, Weissbach H. 1988. Hydroxyproline assay of Kivirikko K.J., Liesmaa M. In: Methods for Plant Molecular Biology. Ed. By A. Wiessbach and H. Wiessbach, Academic Press, Inc. pp. 26-27.

Yamaguchi-Shinozaki K., Shinozaki K. 1999. Biological functions of proline in morphogenesis and osmotolerance revealed in antisense transgenic Arabidopsis thaliana. Plant J. 18: 185-193.

Ye Z-H., Song Y-R., Marcus A., Varner J.E. 1991. Comparative localization of three classes of cell wall proteins. Plant J. 1: 175-183.

\section{Białka ścian komórkowych bogate w prolinę oraz hydroksyprolinę w korze pierwotnej pędów maliny (Rubus idaeus L.)}

\section{Streszczenie}

W pracy badano zawartość białek bogatych w prolinę (PRPs) oraz w hydroksyprolinę (HPRGPs) w korze pierwotnej pędów maliny w okresie sezonu wegetacyjnego. 
Badania przeprowadzono na dwóch odmianach uprawnych - 'Latham' i 'Malling Promise' - różniących się intensywnością wzrostu oraz wrażliwością na stres biotyczny. Zawartość białek PRPs oraz HRGPs zmieniała się w okresie sezonu wegetacyjnego. W okresie późnoletnim, tj. sierpień/wrzesień zawartość tych białek, w szczególności u 'Malling Promise' była kilkakrotnie wyższa niż w okresie wczesnoletnim, tj. czerwiec/lipiec.

Wrażliwość roślin na stres biotyczny oceniana względem grzyba Didymella applanata również zmieniała się w okresie sezonu wegetacyjnego. Odporność pędów, zwłaszcza odmiany podatnej 'Malling Promise', wzrosła w okresie późnego lata. Wzrost odporności był skorelowany ze wzrostem usieciowania ścian komórkowych białkami PRPs oraz HPRGPs. 